\title{
Amilton Barreira: a mentor who left imprints on future neurologists
}

\author{
Amilton Barreira: um mentor que deixou traços em futuros neurologistas \\ Pedro Renato P. Brandão', Luis Augusto Avansini Carnelos², Denise Melo³
}

The Brazilian neurological community lost, on November $14^{\text {th }}, 2018$, a great clinician and researcher and, above all, a remarkable professor of neurological semiology. It is not easy to share with others details about coexistence and learning we gained, as former residents of Prof. Amilton Antunes Barreira (Figure), in the outpatient service and in the Neurology ward, in which he held the position of Full Professor, at the University of São Paulo, in Ribeirão Preto. We have written this short article to record a sample of the great lessons on medical practice, the art of obtaining a detailed anamnesis and performing a thorough physical examination as a process to arrive at a correct diagnosis.

If one could take a poll, with all the neurologists who have learned from Prof. Barreira, we venture to say that ten out of ten would agree that the most striking memories include the rounds in the infirmary on Thursday mornings, at Hospital das Clínicas de Ribeirão Preto. These were a kind of formal ritual. As the first rule, it was necessary to be punctual, at 7 o'clock in the morning. Clinical cases had to have been reviewed in detail with the fellow in neuromuscular diseases the previous afternoon. All data had to be reported in order, beginning with patient identification, the main complaint, duration of symptoms, chronology of disability onset, impact on daily life, comorbidities, and family history. We were instructed by the fellows not to mention any previous diagnosis during the interview, as the professor did not like that - he thought that it could hinder the clinical thinking. As a general rule, the cases were complicated and would have been through more than one diagnosis or treatment in the past, usually unsuccessfully.

The physical examination was an even more formal process. At each reported neurological signal, Prof. Barreira

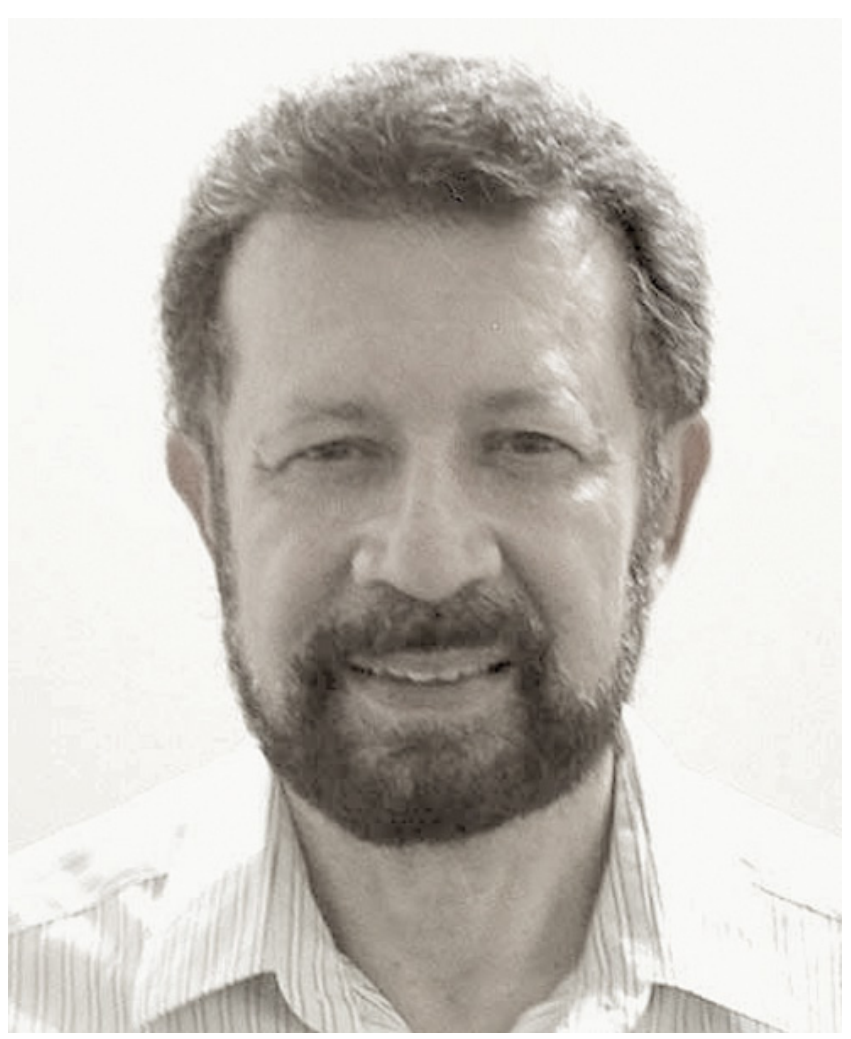

Figure. Prof. Amilton Antunes Barreira (1947-2018) - Full Professor of Neurology at the University of São Paulo Ribeirão Preto - The photo was obtained from his own Facebook account.

extended his hand to the fellow, and requested the Babinski hammer, to confirm or refute the presence of the sign. This was the situation most feared by junior residents, who did not like to be scrutinized over every neurological maneuver.

${ }^{1}$ Câmara dos Deputados, Departamento Médico, Brasília DF, Brasil;

${ }^{2}$ Universidade Federal do Mato Grosso do Sul, Campo Grande MS, Brasil;

${ }^{3}$ Rede Sarah de Hospitais de Reabilitação, Brasília DF, Brasil.

Pedro Renato P. Brandão (iD http://orcid.org/0000-0002-1191-2078; Luis Augusto Avansini Carnelos iD https://orcid.org/0000-0002-8320-2294; Denise Melo (iD) https://orcid.org/0000-0002-3526-0131

Correspondence: Pedro Renato P. Brandão; Congresso Nacional, Câmara dos Deputados, Anexo III, Departamento Médico, Térreo, Ala A, Zona CívicoAdministrativa; 70160-900 Brasília DF, Brasil; E-mail: pedrobrandao.neurologia@gmail.com 
At the end of the always-challenging bedside rounds, everyone sat in the infirmary classroom. Then the second learning process began: clinical reasoning. In this process, each of the participants was asked to give an opinion on the differential diagnosis, on the proposed medical procedures, on possible or instituted treatments. Moreover, in general, the professor used to teach about the historical aspects of each disorder, citing many scientific authorities who had made breakthroughs in the field of neuromuscular disorders or neuroimmunology during recent decades, such as Peter Dyck, Richard A.C. Hughes, Pieter A. van Doorn, Vanda A. Lennon, Nobuhiro Yuki, Richard A. Lewis, and Austin J. Sumner.
Prof. Barreira himself was an authority on many subjects, such as autoimmune ${ }^{1}$ and genetic ${ }^{2,3,4}$ peripheral neuropathies and neuroimmunology, $y^{5,6}$ having advised dozens of professionals and constructed prolific academic production, from basic science ${ }^{7,8,9}$ to clinical practice ${ }^{9,10,11,12}$. He was a reference in autologous hematopoietic stem cell transplantation for multiple sclerosis, ${ }^{12}$ as well as he was a pioneer in nerve biopsy in Brazil and a great enthusiast of the Brazilian Academy of Neurology. We consider, though, that the main imprint he left on his former residents came from the example he set: he molded us into meticulous clinical neurologists and taught us to be committed to our daily work.

\section{References}

1. Wakerley BR, Uncini A, Yuki N. Guillain-Barré and Miller Fisher syndromes: new diagnostic classification. Nat Rev Neurol. 2014 Sep;10(9):537-44. https://doi.org/10.1038/nrneurol.2014.138

2. Barreira AA, Marques W Jr, Sweeney MG, Davis MB, Chimelli L, Paçó-Larson ML, et al. A family with friedreich ataxia and onion-bulb formations at sural nerve biopsy. Ann N Y Acad Sci. 1999 Oct;883(1):466-8. https://doi.org/10.1111/j.1749-6632.1999.tb08612.x

3. Marques W Jr, Freitas MR, Nascimento OJ, Oliveira AB, Calia L, Melo A, et al. 17p duplicated Charcot-Marie-Tooth 1A: characteristics of a new population.J Neurol. 2005 Aug;252(8):972-9. https://doi.org/10.1007/s00415-005-0797-9

4. Pinto MV, Barreira AA, Bulle AS, Freitas MR, França MC Jr, Gondim FA, et al. Brazilian consensus for diagnosis, management and treatment of transthyretin familial amyloid polyneuropathy. Arq Neuropsiquiatr. 2018 Sep;76(9):609-21. https://doi.org/10.1590/0004-282×20180094

5. Brum DG, Luizon MR, Santos AC, Lana-Peixoto MA, Rocha CF, Brito $M L$, et al. European ancestry predominates in neuromyelitis optica and multiple sclerosis patients from Brazil. PLoS One. 2013;8(3):e58925. https://doi.org/10.1371/journal.pone.0058925

6. Brum DG, Barreira AA, dos Santos AC, Kaimen-Maciel DR, Matiello $M$, Costa RM, et al. HLA-DRB association in neuromyelitis optica is different from that observed in multiple sclerosis. Mult Scler. 2010 Jan;16(1):21-9. https://doi.org/10.1177/1352458509350741
7. Santos AP, Suaid CA, Fazan VP, Barreira AA. Microscopic anatomy of brachial plexus branches in Wistar rats. Anat Rec (Hoboken). 2007 May;290(5):477-85. https://doi.org/10.1002/ar.20519

8. Salgado HC, Fazan Júnior R, Fazan VP, Silva VJ, Barreira AA. Arterial baroreceptors and experimental diabetes. Ann N Y Acad Sci. 2001 Jun;940(1):20-7. https://doi.org/10.1111/j.1749-6632.2001.tb03663.x

9. Spedo CT, Frndak SE, Marques VD, Foss MP, Pereira DA, Carvalho LF, et al. Cross-cultural Adaptation, Reliability, and Validity of the BICAMS in Brazil. Clin Neuropsychol. 2015;29(6):836-46. https://doi.org/10.1080/13854046.2015.1093173

10. Gondim FA, Barreira AA, Claudino R, Cruz MW, Cunha FM, Freitas $M R$, et al. Definition and diagnosis of small fiber neuropathy: consensus from the Peripheral Neuropathy Scientific Department of the Brazilian Academy of Neurology. Arq Neuropsiquiatr. 2018 Mar;76(3):200-8. https://doi.org/10.1590/0004-282×20180015

11. Papais-Alvarenga RM, Vasconcelos CC, Alves-Leon SV, Batista E, Santos CM, Camargo SM, et al. The impact of diagnostic criteria for neuromyelitis optica in patients with MS: a 10-year follow-up of the South Atlantic Project. Mult Scler. 2014 Mar;20(3):374-81. https://doi.org/10.1177/1352458513495580

12. Burt RK, Balabanov R, Voltarelli J, Barreira A, Burman J. Autologous hematopoietic stem cell transplantation for multiple sclerosis: if confused or hesitant, remember: 'treat with standard immune suppressive drugs and if no inflammation, no response'. Mult Scler. 2012 Jun;18(6):772-5. https://doi.org/10.1177/1352458512442993 